\title{
8: 6408172-6347601
}

National Cancer Institute

\section{Source}

National Cancer Institute. 8: 6408172-6347601. NCI Thesaurus. Code C41692.

Physical location of ANGPT2_Gene 